\section{The Effect of Basic Education Schools Administers Application of Managerial Accountability in Al-Balqa'a Governorate on Teachers Satisfaction}

\author{
Dr. Bashir Arabiyat \\ Associate Prof. Educational Administration, Al-Balqaa Applied University \\ Dr. Ahmad Mohammad Badah \\ Associate Prof. Educational Administration, Al-Balqaa Applied University
}

Accepted: January 30, 2012 Published: March 24, 2012

Doi:10.5296/ijld.v2i2.1551ＵRL: http://dx.doi.org/10.5296/ijld.v2i2.1551

\begin{abstract}
The current study aimed at identifying the effect of basic education school administrators of managerial accountability in Al-Balqa governorate on teachers' satisfaction. The study population consisted of (22) manager and (5199) teacher. The study used a questionnaire as a tool for gathering the study data.

Results showed that the degree of application of accountability was high for (work and achievement \& job discipline) and medium for the fields (job general ethics \& job humanities). Also, results showed that teachers' satisfaction was medium. Finally, results showed the presence of an effect of managerial accountability and job satisfaction. The study recommended the development of a handbook illustrates the work ethic and commitment to the job and need the teachers in its schools, similar to that in force in the universities.
\end{abstract}

Key Words: Managerial Accountability, Job Satisfaction, Primary Education.

\section{Introduction}

Managerial accountability in administration is considered as one of the most significant issues that deserve renewed attention, and also requires ensuring the proper orientation, performance and management control of all types, whether internal or external or self control, in order to ensure the achievement of the objectives of development and reform programs, in order to maintain the proper use of resources and safeguard the public interest and to achieve secretariat and the integrity of management. 
The principle of accountability when activated, and a practically exercised in the activities of administrative leaders; will be a process to help eliminating the managerial diseases of favoritism, nepotism and waste of time and wasting public money, helping to promote confidence administrative system, and create management more responsive to the needs of citizens, the rule of its presence emphasizes the moral commitment and rationality the rule of law

(Zoubi, 2003).

The educational system and educational management one of the most important systems, which responsible for the construction of the new generations, and its success or failure means success or failure of other social fields. The educational administration is the episode the most important in the structure of the department of education, they are in direct contact with the educational process, the director is the head of the administrative and educational at the same time, a commander directed the decision, which is planned and coordinated and the supervisor in his school. In order to achieve the tasks assigned to school management, accountability in education is a requirement for community groups and segments of all, to ensure the achievement of educational systems to the expectations of their societies (Abu Hamda, 2008).

\section{Study Problem:}

The study problem is represented by identifying the effect of the application of the managers of basic education schools in the governorate of

Al-Balqa of managerial accountability on job satisfaction among teachers.

\section{Study Questions:}

The current study aims at answering the following questions:

1. What is the degree of application of the managers of basic education schools in the governorate of Al-Balqa of managerial accountability in the fields of (work and achievements, job discipline, job general ethics and job humanities).

2. What is the degree of teachers' job satisfaction at basic education schools at Al-Balqa governorate?

3. What is the effect of the application of the managers of basic education schools in the governorate of Al-Balqa of managerial accountability on job satisfaction among teachers?

\section{Study Importance:}

Study importance can be represented by the following:

1. The importance of the study comes from the importance of the subject of the study, which is managerial accountability. Where is the accountability of the most important administrative staff of the administrative process, which is working to provide a fair environment for all administrative staff.

2. Also, importance of the study stems from the importance of the population, where the study includes two categories: education managers and teachers who are working in the schools of basic education. Its based upon themselves to build an educational 
institution a comprehensive and fully able to achieve the aspirations of the Ministry of Education.

3. Finally, findings of the study would participate in the development of decision-makers awareness of the application of management accountability and satisfied with the teachers in basic education schools in the governorate of Balqa.

\section{Study Limits:}

The current study was limited by the following:

1. Time limits: This study was conducted in the academic year (2011-2012).

2. Place Limits: this study was conducted in basic education schools in the governorate of Al-Balqa

3. Objective limits: the results of this study will be determined by the response of basic education schools in the governorate of Al-Balqa managers and teachers.

\section{Previous studies \& Literature Review}

Abu Hamda (2008) conducted a study aimed at identifying the degree of implementation of management accountability and its relationship to the level of job satisfaction for the teachers of private secondary schools of the capital Amman Governorate from the point of view. Study sample was (309) teachers distributed (15) private secondary school in the province of the capital.

The study found that the level of application of managerial accountability in the private secondary schools was high in general, and that the level of job satisfaction for teachers of private secondary schools and teachers in general average, in addition to a statistically significant relation between the level of the application of management accountability and the level of job satisfaction for teachers of private secondary schools and its parameters in the province capital.

Akhwarsheedah (2004) conducted a study aimed to identify the degree of awareness of teachers in public secondary schools in Jordan, the concept of accountability and its relationship with the school effectively. Where the study population consisted of all teachers in government secondary schools and (11490) teachers, the study sample was selected stratified random, which consisted of $(6 \%)$ of the study population and the number of members (585). The study used questionnaire as a tool to gather the study data.

The results showed that the degree of awareness of teachers to the concept of accountability has reached a medium level, and that the degree of effectiveness of public high schools from the viewpoint of teachers was also medium, and the relationship between the degree of awareness of teachers to the concept of accountability and the level of effectiveness of the school is strong.

The aim of the study (Al-Dwairy, 2002) to identify the reality ofthe process of accountability in public administration in Jordan, in terms of awareness of managers to the concept of accountability and practice mechanisms and their opinions about its activation and constraints. The study population consisted of the managers in the (Court of Audit, the Civil Service Bureau, Office of Inspection and Control Management, Ministry of Administrative Development, Directorate of controlled companies in the Ministry of Industry and Trade). 
The results of the study revealed that managers have a high degree of awareness of all aspects of accountability included in the study, the presence of a positive vision to activate accountability by managers surveyed.

Delmer \& Legger (2001) conducted a study aimed to estimate the importance of accountability and responsibility as perceived by managers in local governments in America, where it was from which know the order of relative importance established by or gives these managers the sources and mechanisms of accountability. The study relied on survey data included (858) people from the members of the Assembly district administration and the international cities.

Results of the study revealed a difference in the importance of the sources in connection with a case of a shift in responsibilities from the public during the transition from a focus on the work of a routine to work under the new policy.

A study conducted by George (2001) aimed to identify strategies for educational leaders to raise achievement and meet the new standards of accountability in Florida. The study was conducted on (50) Director and Director, as well as (50) a teacher and used the interview as a means to gather information.

The study found the emphasis on professional development for teachers and school administrators, as well as to organize and develop the curriculum to suit the new standards, and raise the level of examinations and the use of incentives to improve student performance.

\section{Study Methodology}

\section{Study Population and Sample:}

The study had two populations the first population consisted of all basic schools managers at Al-Balqa governorate whom count (211) manager, a random sample of (10\%) was selected for a sample of (22) managers. The second population consisted of all the teachers working in basic education schools at Al-Balqa governorate whom count (5199) teacher, a random sample of (10\%) was selected for a sample of (520) teacher.

\section{Tools of the Study:}

The researcher developed two questionnaires depending on the theoretical literature and previous studies. The first questionnaire was to measure the degree of basic education schools managers' application of managerial accountability at Al-Balqa Governorate. While the second, was to measure the level of basic education schools teacher's job satisfaction in Al-Balqa governorate.

\section{Validity and Reliability of the Study Tools:}

Verified the authenticity of the study tools, and that offer a number of academic specialists in the field of study, to make sure the language of the paragraphs and their suitability for the domain that put into it. It also confirmed the stability of the tools of the study, through testing and retesting, where questionnaire was distributed to a sample reconnaissance, and then distribute the questionnaire two weeks after these individuals, and the extraction factor values (Chronbach alpha) to make sure that the degree of stability of an instrument of the study, which demonstrated the value of coefficient Chronbach alpha for the study variables between 
(0.81-0.94), and this value is acceptable for the purposes of this study as higher than the minimum and stability of (0.60).

\section{Analysis of Study Data:}

Likert scale was used to answer the items of the questionnaire based on the following values: strongly agree (5) points, OK (4) points, agree somewhat (3) points, but OK (2) points, is strongly Disagree (1) point, where it was divided into the following categories:

- $1-2.33 \rightarrow$ low.

- 2.34-3 $66 \rightarrow$ moderate.

- $\quad 3.67-5 \rightarrow$ high.

\section{Results of the study and Discussion:}

Means and standard deviations were calculated for the answers to the members of the sample to answer the study questions.

\section{Answering the study questions:}

This part was to answer the study questions, as follows:

What is the level of organizational climate prevailing in Al-Balqa Applied University / Faculty of Princess Alia University from the viewpoint of the faculty members?

Table (1)

Arithmetic means and standard deviations for the total fields of study Questionnaires

\begin{tabular}{|c|c|c|c|c|c|c|}
\hline Variable & No. & Item & $\begin{array}{l}\text { Arithmetic } \\
\text { Mean }\end{array}$ & $\begin{array}{l}\text { Std. } \\
\text { Deviation }\end{array}$ & Rank & $\begin{array}{l}\text { Importance } \\
\text { Level }\end{array}$ \\
\hline \multirow{4}{*}{ 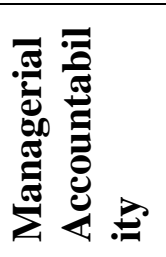 } & $\mathbf{1}$ & work and achievements & 3.72 & 0.92 & 2 & High \\
\hline & 2 & job discipline & 3.88 & 0.83 & 1 & High \\
\hline & 3 & job general ethics & 3.47 & 0.76 & 4 & Medium \\
\hline & 4 & job humanities & 3.62 & 0.87 & 3 & Medium \\
\hline \multicolumn{2}{|l|}{ Total } & Managerial Accountability & 3.76 & 0.94 & - & High \\
\hline \multicolumn{3}{|c|}{ Job Satisfaction } & 3.13 & 0.97 & - & Medium \\
\hline
\end{tabular}

Table (1) shows the results of study sample answers on the study questionnaires, and results of the means and standard deviation of the questionnaires items.

\section{Answering Study Questions:}

According to the results in table (1) above, study questions were answered as follows. First Question: What is the degree of application of the managers of basic education schools in the governorate of Al-Balqa of managerial accountability in the field of work and achievements?

In order to answer the previous question, means and standard deviations were calculated for the answers on work and achievement field. Results in table (1) showed that the field got a mean of (3.72) with high level of importance. 
Second Question: In order to answer the previous question, means and standard deviations were calculated for the answers on job discipline field. Results in table (1) showed that the field got a mean of (3.88) with high level of importance.

Third Question: In order to answer the previous question, means and standard deviations were calculated for the answers on job general ethics field. Results in table (1) showed that the field got a mean of (3.47) with medium level of importance.

Forth Question: In order to answer the previous question, means and standard deviations were calculated for the answers on job humanities field. Results in table (1) showed that the field got a mean of (3.62) with medium level of importance.

Fifth Question: In order to answer the previous question, means and standard deviations were calculated for the answers on job satisfaction questionnaire. Results in table (1) showed that the total mean of the questionnaire was (3.13) with medium level of importance.

Sixth Question: In order to answer the previous question, a hypothesis was written to answer the question, as follows:

- There is no effect of the application of the managers of basic education schools in the governorate of Al-Balqa of managerial accountability on job satisfaction among teachers.

- There is effect of the application of the managers of basic education schools in the governorate of Al-Balqa of managerial accountability on job satisfaction among teachers.

In order to test this hypothesis, multiple regression analysis, thus beta, $(\mathrm{T})$ and significance values, as follows:

Table (2)

Beta, $(T)$ and significance values

\begin{tabular}{|l|l|l|}
\hline Sig. & T & Beta \\
\hline 0.00 & $6.50-$ & $0.29-$ \\
\hline
\end{tabular}

Table (2) above show that beta value was (-0.29), (T) value was (-6.50) with a significance level of (0.00), which is less than significance level of (0.05). This result leads to refuse the null hypothesis and accept the alternative hypothesis, which state that there is effect of the application of the managers of basic education schools in the governorate of Al-Balqa of managerial accountability on job satisfaction among teachers.

\section{Recommendations:}

On the light of the study results, the study recommended the following:

1. Holding workshops and seminars for school principals to explain the importance of accountability in the administrative upgrading of administrative work, and achieve the goals of the institution.

2. Development of a handbook illustrates the work ethic and commitment to the job and need the teachers in its schools, similar to that in force in the universities.

3. Work on further studies to look at the issue of management accountability, and other other areas. 


\section{References}

Delmmer, D. Dunn, Legger, Jr, Jeromes. (2001). U. S. Local Government Managers and the Complexity of Responsibility and accountability in Democratic Governance. Journal of Public Administration Research and theory, Vol. 11, Issue, 1, P. 73.

George, Paul, (2001). A+ Accountability in Florida? Educational Leadership, Vol. 59, No. 1. Washington, Kofa, (2000). An Investigation of the Attitude of Ohio Urban Public school Superintendents Regarding Educational Accountability \& the Comparison of these Attitudes whith those Perceived by Board of Education members, Unpublished Doctoral Dissertation, Bowling Green state University.

Fillet, Farouk Abdu \& Abdel-Majid, Muhammad (2005). Organizational behavior in the management of educational institutions, Ed 1, Amman: Dar al-Maseerah for publication and distribution.

Zoubi, Maison (2003). Degree of implementation of administrative accountability in the departments of Education in Jordan and the constraints applied. Unpublished PhD thesis, Amman Arab University for Graduate Studies, Amman, Jordan.

Al-Dwairy, Ahmed Odeh, (2002). Accountability in public administration in Jordan: a field study of the analytical point of view of managers in the Ministry of Administrative Development and central control. Unpublished Master Thesis, Yarmouk University, Irbid, Jordan.

Abu Hamda, Saada Ahmed (2008). Degree of implementation of management accountability and its relationship to the level of job satisfaction for teachers of private secondary schools of the capital Amman Governorate from the point of view. Unpublished Master Thesis, University of the Middle East, Amman, Jordan.

Akhwarsheedah, Alyah Khalaf (2004). Awareness of teachers in public secondary schools in Jordan, the concept of accountability and the relationship of Zpk effectively the school. Unpublished PhD thesis, Amman Arab University for Graduate Studies. Amman, Jordan. 